УДК 004.415:37 (477)

Пірко Марина Василівна, молодший науковий співробітник Інституту інформаційних технологій і засобів навчання Національної Академії педагогічних наук України, м. Київ

\title{
АКТУАЛЬНІ АСПЕКТИ ДОСЛІДЖЕННЯ ПРОБЛЕМ ВИЗНАЧЕННЯ ЯКОСТІ ПРОГРАМНИХ ЗАСОБІВ НАВЧАЛЬНОГО ПРИЗНАЧЕННЯ ЗАГАЛЬНООСВІТНЬОГО СЕРЕДОВИЩА В УКРАЇНІ
}

\section{Анотація}

У статті розглянуто й описано актуальні аспекти дослідження проблем досягнення високого рівня якості освіти, проблем визначення якості програмних засобів навчального призначення загальноосвітнього середовища в Україні на сучасному етапі створення єдиного освітнього простору в Україні. Описано етапи спрямування досліджень в умовах формування глобального міжнародного освітнього середовища і єдиного інформаційного простору системи освіти. Звернуто увагу на необхідність проведення грамотної і ретельно відпрацьованої технологічної політики під час, коли рівень доступності освіти зростає, і проблема якісної освіти набуває соціального характеру.

Ключові слова: глобальне міжнародне освітнє середовище (ГМОС), Державний Освітній Стандарт (ДОС), єдиний інформаційний простір системи освіти (ЄІПСО), інформаційне суспільство, інформаційні продукти (IП), інформаційні системи (IC), інформаційні технології (IT), технічний прогрес (ТП), якість освіти.

Постановка проблеми. Життєдіяльність сучасного суспільства багата широким використанням комп'ютерних i телекомунікаційних інформаційних технологій (IT). Розвиток IT відзначився глибоким і всеохоплюючим проникненням у всі сфери діяльності й відносин людей, і викликає зміни не тільки у сфері виробництва, а й у національній, військовій, сфері міжнародних торгових i фінансових зв язків, і що особливо вагомо, у сфері освіти всіх розвинутих країн світу, які стали свідками й учасниками формування нового явища - глобального 
міжнародного освітнього середовища (ГМОС), і єдиного інформаційного простору системи освіти (СІПСО) [1, с. 61].

Метою цієї статті є висвітлення ключових проблем визначення якості програмних засобів навчального призначення на сучасному етапі створення єдиного освітнього простору в Україні, напрямків їх опрацювання, етапів, якими має спрямовуватися дослідження.

Виклад основного матеріалу. Головним двигуном розвитку ГМОС є індустрія IT, яка розповсюджує популярний вид продукції - інформаційні продукти (IП). Інформаційний продукт - це різні дані, витвори мистецтва, різноманітні повідомлення, розваги, і знання, отримані як традиційним шляхом, так і за допомогою електронної техніки.

Реалії сьогодення такі, що рівень технологічного розвитку країни визначає іiі економічний розвиток, національну безпеку, роль і місце у світовій спільноті. Рівень розвитку сучасних технологій в кожній окремій країні залежить не тільки від розвитку відповідної матеріальної бази, а також від інтелектуального потенціалу суспільства, рівня розвитку освіти країни [6]. Провідна роль освіти сучасного суспільства, XXI століття, визначається науково-технічною революцією і глобальною технологізацією найбільш розвинутих країн світу.

Поточні перетворення репродуктивних сил суспільства нагально потребують змін і загальноосвітньої, i професійної шкіл, які забезпечують відтворення кваліфікованої робочої сили. Темпи технічного прогресу (ТП) нині все більш залежні від рівня якості освіти, який змінюється, відображаючи нові потреби суспільства, обумовлені розвитком науки і виробництва (рис. 1).

За словами Аристотеля, що «Благо будь-де залежить від дотримання двох умов: правильного встановлення кінцевої мети i пошуку відповідних засобів, для досягнення цієї мети». Рівень якості освіти складається з:

- організації освітнього процесу і його складових;

- технологічного забезпечення суб 'єктів навчальної діяльності.

Програмні засоби, якісні програмні засоби навчального призначення, у тому числі, і є однією із складових технологічного забезпечення процесу навчання з метою досягнення високого рівня якості освіти. 
I тому «...перед освітою постало складне двоєдине завдання: вона повинна осучаснюватися на основі новітніх технологій через широке впровадження у навчально-виховний процес IКТ, а також - формувати у молоді риси, необхідні для успішної самореалізації в інформаційному суспільстві після завершення навчання в школі...», - наголошується в [5].

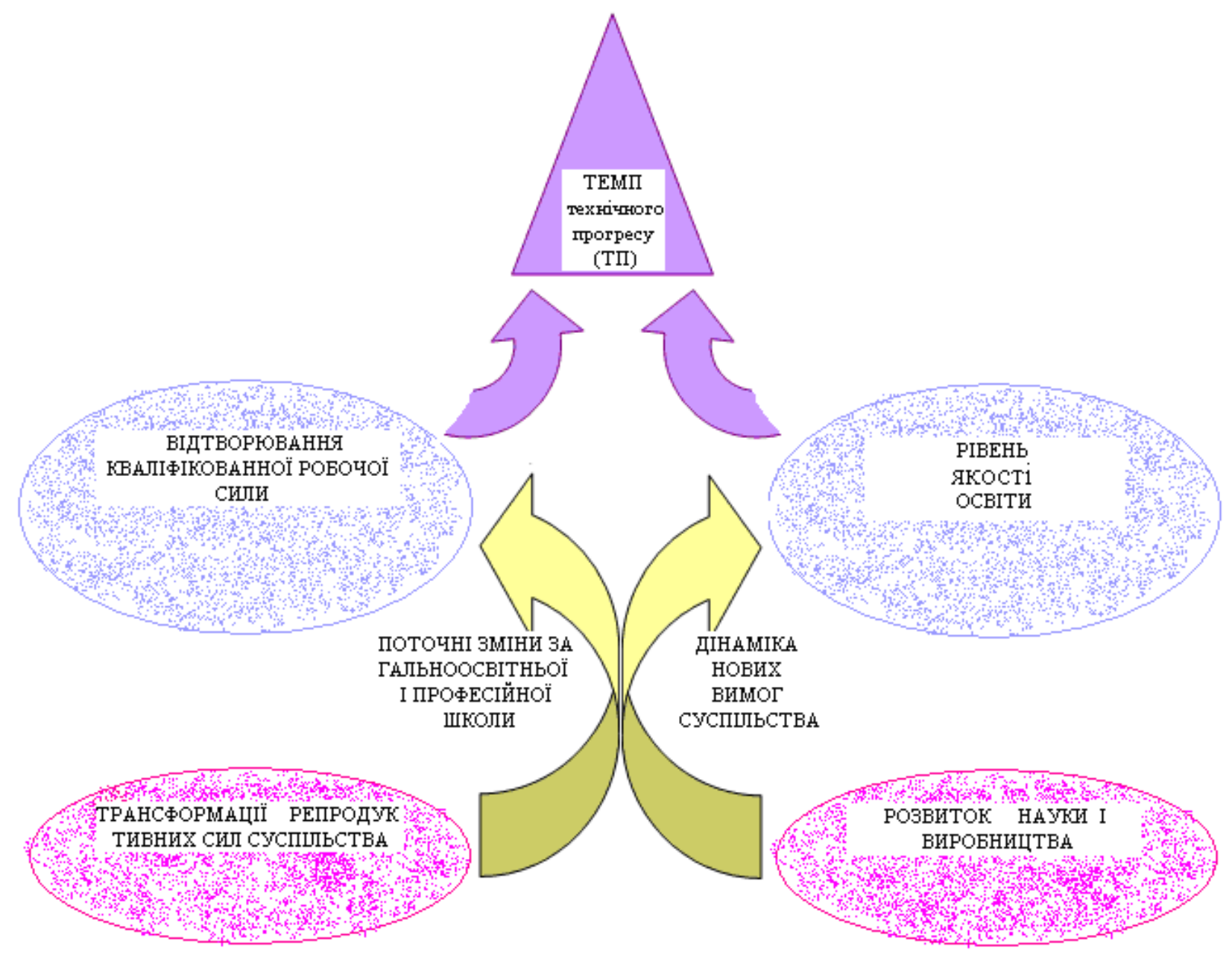

Рис. 1. Темпи технічного прогресу (ТП) нині все більш залежні від рівня якості освіти

Усе це ставить перед освітою нові, складніші завдання виховання і навчання молоді й одночасно ініціює створення досконаліших засобів, технологій навчання для розв’язання таких задач. Найперспективнішими серед них є засоби і технології, пов’язані з інформатизацією. Інформатизація науки і освіти є випереджувальною, бо саме в цьому середовищі «в основному формується когнітивний, кадровий і науковотехнічний фундамент самої інформатизації як процесу і соціально-економічного явища, закладається майбутнє досягнень і розвитку суспільства в цілому», - так зазначено Валерієм Биковим [1, с. 40]. 
Дослідження в галузі інформатизації освіти реалізовуються з кінця 80-х років ХХ ст. за часів СРСР, в Україні із середини 90-х років ХХ ст., і підкріплені програмами на державному рівні.

Значна кількість досліджень присвячена різним аспектам інформатизації освіти. Разом із тим, дослідження загальних методів і закономірностей створення i використання засобів 3 урахуванням напрямків реформування освіти, що здійснюються в системі освіти, сучасного стану інформатизації освіти і розвитку інформаційних технологій в Україні тривають.

Нині суттєво впливають на рівень якості освіти, відповідно і на ефективність використання засобів навчального призначення, і на їх якість, проблеми: Академічної мобільності; Вибору моделі навчального повідомлення; Проблеми інформаційної безпеки; Ускладнення інформаційних технологій; Уніфікаџії технологій подання $i$ обробки навчальних даних; Економічної неефективності; Управління якістю освіти.

Академічна мобільність. Під час процесу трансформаційних перетворень фактом є невідповідності як з вимогами суспільства, і змінами освітніх стандартів у межах конкретної країни, також і освітніх стандартів держав, окремих університетів. Звертаючи увагу, що з часів здобуття Україною незалежності, i 3 розвитком освітнього середовища України, у джерелах якого спадщина освітньої системи СРСР, тобто, майже всі невідповідності є наслідками історичних, етнографічних, релігійних, політичних та інших причин.

Досягнення академічної мобільності вимагає, у найкращому випадку, змін освітніх стандартів так, щоб стандарти різних країн не відрізнялися один від одного, або таких змін, щоб ці відмінності були мінімальними, залежно від етнографічних, політичних та ін. причин.

Вибір моделі навчального повідомлення. Різноманітність джерел навчальних матеріалів мережі сьогодення, наприклад: Вікіпедія, Острів знань, Moodle, Networks, Web of Asynchronous Learning i т. п., з навчальними курсами включно, розподілені за темами, де кожна сторінка теми має посилання на подібні курси.

Ресурси сумісного використання $є$ частиною, компонентом складного навчального матеріалу (приклад, розділ підручника). Теж саме стосується і допоміжних засобів (карти, плакати тощо), і підручників (необхідність конкретної теми у підручнику). Необхідні більш удосконалені системи категоризації, пошуку, 
серйозні механізми для оновлення і подання повідомлень. Тісний зв'язок навчальних ресурсів із загальними і частковими цілями навчання, за повного забезпечення наповнення індивідуальних навчальних програм. Водночас необхідна незалежність ресурсів від дрібних навчальних планів.

Отже, навчальний курс - не $€$ найприйнятнішим ресурсом сумісного застосування.

Проблеми інформаційної безпеки. Під інформаційною безпекою розуміють захищеність інформаційних ресурсів й інфраструктури підтримки від випадкових або заздалегідь спланованих впливів природного або штучного характеру, з високою вірогідністю нанесення пошкоджень суб’єктам інформаційних відносин, у тому числі власникам i користувачам ресурсів й інфраструктури підтримки. Захист інформаційних даних — це комплекс заходів для забезпечення інформаційної безпеки. Правильний з методологічної точки зору підхід до проблем інформаційної безпеки становить виявлення суб'єктів інформаційних відносин й інтересів цих суб'єктів, пов'язаних із використанням інформаційних систем. Погрози інформаційній безпеці - зворотна сторона використання інформаційних технологій.

Вважалося аксіоматично, забезпечення безпеки інформаційних ресурсів $\epsilon$ єдністю складових: Конфіденціийність, Цілісність, Доступність. Сам процес захисту щодо інформаційної системи грунтується на: апаратному забезпеченні, програмному забезпеченні, забезпеченні зв'язку (комунікації). Саме процедури (механізми) захисту розподіляються на: «..захист фізичного рівня, захист персоналу, організаційний рівень...» [2].

Інформаційна сфера сучасного соціуму складається 3 інформаційно-технічної (штучно створеної людиною - світ техніки, технологій і т. ін.) й інформаційнопсихологічної (світ живої природи, із самою людиною включно). Тобто, узагальнюючи інформаційну безпеку ресурсів, можливо подати як: інформащійнотехнічна безпека і інформачійно-психологічна (психофізична) безпека.

Інформаційна безпека (від англ. information security) — це всі аспекти, пов’язані з визначенням, досягненням і підтримкою конфіденційності, цілісності і доступності, безперебійності, звітності, автентичності і достовірності даних або засобів обробки їх.

Безпека ресурсів (даних) - (англ. information (data) security) стан захищеності ресурсів (даних), за якого їх конфіденційність, цілісність і доступність забезпечені. 
Саме інформаційна безпека - захист конфіденційності, цілісності і доступності ресурсів (даних). Безпека ресурсів (даних) визначається, відсутністю ризику, пов’язаного 3 втратою цілісності ресурсів технічними каналами, несанкціонованим впливом на ресурси та інші дані автоматизованої інформаційної системи, які використовуються автоматизованою системою.

Безпека інформаційних ресурсів (за умови використання інформаційних технологій) (англ. IT security) - стан захищеності ресурсів, із забезпеченням безпеки ресурсів, для обробки яких вона застосовується, й інформаційну безпеку автоматизованої системи, у якій вона реалізована.

Під інформаційною безпекою слід розуміти захист інтересів суб'єктів інформаційних відносин.

Ускладнення інформаційних технологій. Відомо, що читання 3 монітору комп'ютера значно уступає за комфортністю книжці. Тому, підкреслюючи реальну користь, навчальний матеріал в електронній формі має забезпечувати додаткові можливості для користувача. Мова йде про грамотну навігацію за матеріалами курсу і використання мультимедія. Суперечності 3 необхідністю широкомасштабного створення електронних посібників у цьому завданні очевидні. Фахівцям інших галузей складно використовувати прогресивні інформаційні засоби. Тому використання базових засобів, які забезпечують обмаль можливостей, очевидна.

Уніфікація технологій подання й обробки навчальних даних. Сучасні учні активні користувачі інформаційних ресурсів, які використовуються сумісно. Тобто, ті ж самі підручники, 3 усіма ознаками сумісного використання: спроектовані, виготовлені і використовуються викладачами й учнями всього світу. Окрім підручників, географічні карти, періодичні таблиці хімічних елементів, різні комп'ютерні прилади, графічні редактори. Практично неможливо визначити відповідність формату, масштабів, методології освітнього рівня або представлення ресурсів: деякі з навчальними цілями включно, інші ні. Решта написані в Јava, інші в HTML, або ще у якому-небудь гібриді, відомому тільки автору. Одні вимагають від учня 10 хвилин його часу, інші займають весь день. І відсутні будь-які структуровані засоби у викладача, щоб дізнатися, що є що. Окрім цього, труднощі обслуговування курсів сумісного використання різними установами (різні технологічні платформи, різні принципи систем управління навчанням тощо). 
Економічна неефективність. Згідно Державному Освітньому Стандарту, предмет «Алгебра і початки аналізу» в переліку обов'язкових дисциплін, тобто, обсягом, встановленим ДОСом має викладатися в кожному середньому загальноосвітньому закладі ІІ-го, ІІІ-го ступеню, ліцеї, технікумі, коледжі в Україні. Тема «Показникова i логарифмічна функції» - одна із складових дисципліни «Алгебра і початки аналізу». Кожна така тема, окрім всілякої навчальної інформації, укомплектована й описами показникової і логарифмічної функцій включно. Отже, маємо певну кількість однакових описів показникової і логарифмічної функцій (властивості функції не залежать від форми і стилю опису). Припустимо, деякі навчальні заклади вирішать помістити свої інтерпретації цієї теми в Інтернеті, у результаті отримаємо в мережі певну кількість однакових описів показникової і логарифмічної функцій. Фактично: чи необхідна освітній системі з можливостями сучасних IT така кількість подібних інтерпретацій, якщо опис показникової i логарифмічної функцій розміщений на правах відкритого доступу в мережі і його можна скопіювати з будь-якої точки земної кулі. Більш того, створення якісної інтерпретації теми (текст, графіка, анімації, практикуми і т. п.) речі дорогої вартості. Чи варто витрачати час, гроші і зусилля на створення інтерпретацій близнюків.

Управління якістю освіти. Якість нині - серед ключових проблем цивілізації: якість повідомлень, якість політики, якість виробництва, якість техніки і технологій, якість культури, науки - назвемо будь-який напрям діяльності людини і скрізь якість виступає визначним чинником стану, розвитку і перспективи рішення питань. Проблема якості постає в центрі проблем епохи глобалізації. Від підвищення якості освіти, освітніх послуг залежить можливість становлення нової сучасної, так званої інформаційної цивілізації.

Скорочення життєвого циклу знань обумовлює необхідність безперервного навчання, тобто, навчання впродовж усього життя. I вимоги до якості знань, і відповідно, до якості освітніх послуг з часом змінюються. Прагнення підвищення освітнього рівня членів суспільства зумовлює необхідність «розвитку системи освіти - підвищення доступності освіти, розширення спектру і поліпшення якості освітніх послуг» $[1$, с. 18$]$.

В умовах, коли рівень доступності освіти зростає, проблема якісної освіти набуває соціального характеру. Це пов'язано з можливістю найкращої реалізації 
здібностей і можливостей людини, з отриманням відповідно кращого місця роботи (кращого місця подальшого навчання) i винагородами за кваліфіковану працю. Водночас якість освіти пов'язана 3 ефективнішою реалізацією національного потенціалу розвитку країни нині. Якість освіти стає провідним інструментом не тільки внутрішньої національної політики і значним фактором міжнародного впливу, міжнародного престижу.

Основні напрямки реформування освіти України, висвітлені в статті В. Г. Кременя [4], і Законі України «Про основні засади розвитку інформаційного суспільства в Україні на 2007-2015 роки» [3], у якому дана оцінка сучасного стану інформатизації освіти України і визначені основні напрямки ії розвитку на період до 2015 року, що включають розширення доступності освіти, підвищення іiі якості й ефективності. У тому числі, думка про підвищення якості освіти посідає центральне місце в концепції модернізації освіти, і в усій теперішній політиці міністерства.

Враховуючи умови Болонського процесу, де з числа найважливіших п'яти проблем виокремлено якість сучасної освіти і створення сучасних критеріїв $i$ методології, перед системами освіти країн постають складні завдання. Серед них для України постає завдання не тільки увійти повноправним партнером у Свропейський i світовий освітні простори, але і зберегти престиж національної системи освіти.

Якість освіти - складне і багатофакторне поняття. До нього входять:

Biдnовідності змісту освіти вимогам розвитку країни й інтересам особистості учнів;

Сучасність системи освіти;

Cmуnінь реалізації навчальним закладом освітніх задач (як загальноосвітніх, так і задач для вищої і професійної шкіл).

Категорія «якості освіти» на сучасному етапі розвитку суспільства є інтегрованою з декількох галузей: акмеології, аксіології, квалітології, кваліметрії та ін., які є джерелами специфічних підходів до визначення поняття «якості» взагалі, i «якості програмних засобів навчання» так само, яка $є$ однією із складових якості освіти.

Необхідність розробки структурованого пакета документів, які регламентують аспекти діяльності Інтернет-організацій (3Н3, ліцеїв, коледжів, ВНЗ, корпоративних навчальних систем і т. ін.), очевидна. За такою документацією 
встановлюватимуться вимоги і рекомендації, як повинні відбуватися управлінські процеси в установі з метою ефективного бізнесу, визначатимуться вимоги, пов’язані iз забезпеченням якості освітніх послуг. Метою формування пакета документації 3 Управління якістю є найефективніше рішення проблеми оптимальної організації системи, стимулювання процесів удосконалення, які гарантують постійне покращення процесів управління.

Необхідність проведення грамотної і ретельно відпрацьованої технологічної політики (не зважаючи на думку більшості, що сильна політика, наприклад, уведення стандартів, здатна уповільнити процес широкомасштабного створення освітніх інформаційних ресурсів) продиктована реаліями сьогодення. Сучасні інформаційні технології і методи досягли такого рівня, що значно спрощують задачі авторам електронних навчальних матеріалів. Але, вище означені проблеми є ключовими під час організації єдиного освітнього простору в Україні. I опрацювання їх має спрямовуватися етапами:

емпіричний, на якому констатуються певні особливості (про сукупності показників якості засобів ІКТ навчального призначення);

етіологічний, вивчаються джерела тих чи інших особливостей;

типологічний, визначається той або інший тип розвитку, той або інший шлях наступного розвитку (про високоформалізовані моделі);

діагностичний;

прогнозування, потребує вміння передбачення наступного шляху розвитку на підставі пройдених етапів (різноманітність трактування педагогічних покажчиків у роботах різних авторів);

педагогічне призначення і визначення шляхів корекції.

Висновки. Постачальникам інформаційних послуг, освітніх зокрема, для забезпечення собі достойного місця в інформаційному просторі варто розширювати свою участь на всіх стадіях проектування, впровадження й експлуатації інформаційної продукції. Перш за все необхідно зосередити увагу на систематизації освітніх інформаційних ресурсів і стандартизації засобів технологічної підтримки.

\section{Список використаних джерел}

1. Биков В. Ю. Моделі організаційних систем відкритої освіти / В. Ю. Биков //Київ: Атіка, 2009. - 684 с. 
2. Вікіпедія - вільна енциклопедія. - [Електронний ресурс]. - Режим доступу:

http://ru.wikipedia.org/wiki/\%D0\%A4\%D0\%B0\%D0\%B9\%D0\%BB:Information_securitycompon ents_JMK.png.

3. Закон України «Про основні засади розвитку інформаційного суспільства в Україні на 2007-2015 роки» від 9 січня 2007 року № 537-V. — http://zakon.rada.gov.ua/cgi-bin/laws/main.cgi.

4. Кремень В. Г. Суспільство знань і якісна освіта / В. Г. Кремень // Освіта. 2007. — № 13-14, 21-27 березня.

5. Освіта в інформаційному поступі суспільства / Доповідь на підсумковій колегії Міністерства освіти і науки України 17 серпня 2006 року // Освіта України. — 2006. - 14 серпня (№ 60-61). - С. 1-21.

6. Титарев Л. Г., Хорошилов А. В. Информационные образовательные технологии и качество образования. Материалы Всероссийской конференции «Роль информационных технологий при обучении на программе МВА» / Л. Г. Титарев, А. В. Хорошилов. 30-31 января 2003 г. // Москва: МЭСИ, 2003. - С. 241-260.

\section{АКТУАЛЬНЫЕ АСПЕКТЫ ИССЛЕДОВАНИЙ ПРОБЛЕМ ОПРЕДЕЛЕНИЯ КАЧЕСТВА ПРОГРАМНЫХ СРЕДСТВ ОБУЧЕНИЯ СРЕДНЕЙ ОБЩЕОБРАЗОВАТЕЛЬНОЙ ШКОЛЫ В УКРАИНЕ}

\section{Пирко М. В.}

\section{Аннотация}

В статье рассмотрены и описаны актуальные аспекты исследований проблем достижения высокого уровня качества образования, актуальные аспекты исследований проблем определения качества программных средств обучения в средней образовательной школе в условиях создания единого информационного пространства системы образования в Украине. Описаны этапы направлений исследований в условиях формирования глобальной международной образовательной среды. Обращено внимание на необходимость проведения грамотной и тщательно изученной технологической политики в период, когда уровень доступности образования растет и проблема качественного образования приобретает социальный характер. 
Ключевые слова: глобальная международная образовательная среда, Государственный Образовательный Стандарт, единое информационное пространство системы образования, информационное общество, информационные продукты, информационные системы, информационные технологии, качество образования, технический прогресс.

\section{ACTUAL ASPECTS OF RESEARCHES OF LEARNING TOOLS QUALITY DEFINITION PROBLEMS OF SECONDARY SCHOOL IN UKRAINE \\ Pirko M.}

\section{Resume}

In the article actual aspects of researches of problems concerning achievement of a high level of education quality, actual aspects of researches of problems concerning definition of programming learning tools quality at secondary school in the conditions of creation of unified educational space of educational system in Ukraine are considered and described. Stages of directions of researches in the conditions of global international educational environment formation are described. The attention is paid to the necessity of carrying out of competent and carefully studied technological policy during the period when level of education availability is growing as well as a quality education problem is getting a social character.

Keywords: global international educational environment, State Educational Standard, unified information space of education system, information society, information products, information systems, information technology, quality of education, technical progress. 